Review Article

\title{
Technologies for Intensification of Production and Uses of Grain Legumes for Nutritional Security
}

\author{
P JANILA, S RUPAVATHARAM, C V SAMEER KUMAR, S SAMINENI, P M GAUR* and \\ R K VARSHNEY \\ International Crops Research Institute for Semi-Arid Tropics (ICRISAT), Patancheru, Telangana, India
}

(Received on 26 June 2016; Accepted on 22 July 2016)

\begin{abstract}
Malnutrition resulting from intake of food poor in nutritional value, particularly lacking in micronutrients, has been recognized as a serious health problem in developing countries including India. Nutritional security is a priority for India. Crop diversification in agriculture contributes to balanced diet and nutritional security. Production intensification of nutrient-dense crops, contributes to their increased production, and consequently enhances their accessibility at affordable prices to meet nutritional security. Grain legumes produce nutrient-dense grains rich in proteins, vitamins, minerals and micronutrients essential for growth and development. However, cultivation of grain legumes is often neglected resulting in poor production in the country, and consequently poor access to legumes at affordable prices. Pigeonpea or red gram (Cajanus cajan L.), chickpea or bengal gram (Cicer arietinum L.) and groundnut (Arachis hypogaea L.), the three nutritious grain legumes are grown widely across the country and are major constituents of Indian diets. They are climate- resilient crops adapted to water-limiting conditions making them choice crops for cultivation in adverse conditions. Policy options for promoting cultivation and increased production of pigeon pea, chickpea and groundnut are needed. Technology options for intensification of their cultivation include improved cultivars of grain legumes with enhanced adaptation and nutritional properties, their processing, plugging post-harvest and storage losses, and development of alternative food products. The chapter discusses the contribution of agriculture to nutritional security and the need to diversify cultivation of crops to include nutrient-dense grain legumes, and intensification of their cultivation to achieve their enhanced production and productivity. The scope to develop bio-fortified grain legumes is also discussed. Some countries have successfully harnessed the potential of processed grain legumes for use as food supplements for children and elderly, as well as to prepare readyto-use-therapeutic-food products to treat acute malnutrition.
\end{abstract}

Keywords: Malnutrition; Nutritional Security; Grain Legumes; Bio-fortification

\section{Introduction}

Access to adequate food, proper feeding practices, and sanitation and health care are the three determinants of 'nutritional security'. Food security is key to achieve nutritional security. UNICEF describes nutritional security as a 'quality' aspect of food, its consumption and satisfactory use for utilization by all individuals in a household. A person is considered nutrition-secure when she or he has a nutritionally adequate diet and the food consumed is biologically utilized to ensure adequate performance in terms of growth, resistance or recovering from disease, pregnancy, lactation and physical work (Pangaribowo et al., 2013). Nutritional security should be a priority in all places in the world where food security is a challenge. UN World Food Program has reported that more than 900 million people in the world do not get right/nutritious food to eat. In this review there is a conscious focus on under-nutrition which is more common in India.

India is the world's third largest economy and has demonstrated significant growth in terms of Gross Domestic Product (GDP). However, India is an example of a development paradox. Despite recording a high growth rate of $10-14 \%$ in the last 2 decades, life expectancy, standard of living and education are low. The relationships between poverty and malnutrition are well researched and documented.

*Author for Correspondence: E-mail: p.gaur@cgiar.org 
Nutritional insecurity is often the consequence of food insecurity (Varadharajan et al., 2013). One third of worlds undernourished children live in India and there are several reports of under-nutrition being the predominant form of malnutrition in India. National Sample Survey (NSS), 2011-12 shows that over 51.8\% of rural households depend upon public distribution system (PDS) for source of food i.e. rice and wheat which are the primary sources of carbohydrates and proteins (Narayanan and Gerber, 2016). Inclusion of legumes and millets under PDS and awareness regarding their inclusion in regular diets can help to alleviate the burden of under-nutrition in the country.

Considering the impact of malnutrition on human health and growth, UN had included malnutrition in its Millennium Development Goals (MDGs) for period 2000-2015. On September $25^{\text {th }} 2015$, countries adopted a set of Sustainable Development Goals (SDGs) to end poverty, protect the planet, and ensure prosperity for all. Each goal has specific targets with a total of 169 targets to be achieved over the next 15 years. Zero hunger, Good health and wellbeing, clean water and sanitation are three SDGs that contribute to achieve nutritional security. To achieve this, UN and several international organizations and national governments are committed to eradicate hunger, malnutrition and ensure food and nutritional security by responding to nutritional needs, addressing emerging threats and meeting the zero hunger challenge. International Crops Research Institute for Semi-Arid Tropics (ICRISAT), an international research organization with headquarters in Hyderabad-India is committed to contribute to achieve SDGs through its research and developmental activities across Africa and Asia. ICRISAT's mandated crops are climate resilient and nutrient dense, and include Sorghum, pearl millet and finger millet, chickpea, pigeon pea and groundnut.

\section{Contribution of Agriculture to Nutritional Security}

Recognition of the need for nutrition-sensitive development is gaining momentum and catalyzing agricultural research towards achieving nutritional security. Work on tackling the agriculture-nutrition disconnect in India (TANDI) was initiated in 2010-12 by the International Food Policy Research Institute (IFPRI) to understand and address the failure of economic and agricultural growth in reducing malnutrition in India. This initiative enabled economists, nutritionists and other stake holders to build a consensus for key pathways between agriculture and nutrition in India. This helped to understand the key knowledge gaps and facilitate changes in India's agriculture policy and programmes towards addressing nutritional security. Kandiyala et al. (2014) reported pathways between agriculture and nutrition in India after reviewing 22 observational studies using analytical methods along with 49 studies which used quantitative and descriptive statistics. The pathways are summarized below:

(a) Crop diversification in agriculture contributed to a positive association with dietary diversification (Bhagowalia et al., 2012). Diversifying cropping system such as mixed cropping system in agriculture, kitchen garden at family level and school kitchen gardens could help to improve nutrition.

(b) Agriculture as a source of income for food and non-food expenditures revealed the paradox of income and expenditure as important determinants of quality diet. Nutritional impacts were slow despite rapid economic growth in India (Deaton and Dreze, 2009).

(c) Agricultural policy and food pricing affects food consumption. Large increase in prices of a commodity (for example pulses) seem to impact their consumption. Likewise decline in relative prices of fruits appeared to explain rapid rise in fruit consumption. Contrastingly, trade liberalization affected relative price and income with potentially reduced protein and calorie intake by the poorest people (30\%) in both rural and urban India (Panda and Ganesh-kumar, 2009).

(d) Women in agriculture and intra-household decision making for resource allocation had direct impact on nutritional status and dietary diversity (Bhagowalia et al., 2012). Women in agriculture and poor maternal nutrition were found to be linked. Thinness of women in farming communities was high compared to women in non-farming families as the former were found to be working for longer hours in farming as well as carrying the extra burden of household chores (Barker et al., 2006). 
(e) Economic recession and income instability within households increased women's labour participation in agriculture which in turn had detrimental effects on health care and nutritional status of women and children. There is a higher risk of infant mortality up to $50 \%$ under such circumstances (Bhalotra, 2010).

More than $80 \%$ of farmers in India have small and marginal land holdings ( $<2$ ha). Wiggins and Keats (2013) reported that smallholder agriculture has potential to affect food security and nutrition through diverse interventions. The report suggests empowerment of women farmers, promotion of home gardens and small-scale diversification of farms through livestock rearing, bio-fortification of staple foods with vitamins and iron, complement agricultural programs with education, communication, health services and sanitation, inclusive policies for nutritionsensitive development, and improving leadership and political conditions influenced nutritional security.

India's poor progress in tackling malnutrition is a global concern. Addressing this issue requires nutrition-specific and nutrition-sensitive agricultural interventions. The existing literature suggests the potential role for the development of nutrition-sensitive agriculture. It is evident from the recent studies that agriculture-nutrition research needs to be broadened to a more open and dynamic forum for interdisciplinary collaborations (Kadiyala et al., 2014).

Another potential area of intervention is plugging postharvest and storage losses of agricultural produce. In low- and middle- income countries like India, postharvest losses contribute to $40 \%$ of total food loss from its production to consumption (FAO, 2011). The FAO study also illustrates the need to plug post-harvest losses to achieve food security. In India production of food grains including grain legumes has been steadily increasing due to advancement in production technology, however losses have remained static. Post-harvest losses in India amount to 12 to 16 million metric tons of food grains each year- an amount that the World Bank estimates could feed one-third of India's poor (Nagpal and Kumar, 2012). In India, postharvest losses amount to $10 \%$ of total food grains produced that include cereals, pulses, and oilseeds. The main reason for this is improper postharvest handling and storage methods. An average of $6 \%$ out of a total $10 \%$ loss takes place during storage of food grains (http://www.fao.org/Wairdocs/X5002E/ X5002e01.HTM\#Preface). Compared to cereals, high protein and oil content in pulses and grain legumes make them prone to more storage losses. Consequently, grain legumes suffer much higher damage from insects and microorganisms than cereals and result in both quantity and quality losses. Insects, such as Bruchids are a serious pest in storage, they cause severe milling losses as a consequence of breakage and powdering of infested grains. For instance, the postharvest losses of pulses from harvest, storage to transport vary from 25 to $30 \%$ of total production of pulses in the country (Lal and Verma, 2007). The huge quantity of post-harvest and storage losses also contributes to reduced accessibility of pulses at affordable prices. Development of appropriate post-harvest handling and storage methods as well as training the farmers on post-harvest technology for drying, processing of grains and pulses are important to minimize the storage losses. Milling and storage are key postharvest operations. While small scale milling with traditional methods and machines are popular in India, large- scale milling and storage methods are wanting and they need scientific innovation.

\section{Grain Legumes for Nutritional Security in India}

A combination of cereals- rice or wheat with grain legume is a popular daily diet across Indian states. 'Dal-chawal' or 'dal-roti', makes a healthy diet as legumes contribute protein, and micronutrients, and cereals contribute carbohydrates. However, in general the quantities of legumes compared to cereals consumed are far below the recommended level creating dietary and nutritional imbalance. Unfortunately, people with better livelihoods are also prone to malnutrition due to lack of dietary diversification. Diversifying agricultural production and intensification of production of nutrient-rich grain legumes will increase access to legumes and thus dietary diversity.

Grain legumes can play a greater role in enhancing nutritional security irrespective of age, gender and economic groups as these crops are rich in proteins and have higher dietary fibre, mineral contents, phenolic compounds, and vital vitamins for growth and development. Grain legumes such as 
chickpea, pigeon pea and groundnut have high nutritional value (Table 1). They can be cultivated on marginal soils by resource- poor farmers. They are resilient to climate change and have adaptive features for limited water, high temperatures and low-nutritional status of the soils. They are often cultivated by smallholder farmers and contribute to improved access to legumes within the household as well as in rural markets. These legumes have additional features of nitrogen fixation, mineral acquisition from deeper soil layers, and addition of organic matter to the soil in the form of leaf drops and decaying roots contributing to soil health improvement and stability of agroecosystems. High-yielding cultivars of chickpea, pigeonpea and groundnut have been released for cultivation and some of them have been adopted by the farmers to realize higher yields. Further genetic improvement for higher yield and adaptation traits can contribute to increased production of legumes. Improved cultivars of these crops are also more responsive to better crop management for higher grain yield, making them more relevant to contributing to nutritional security in areas where they are traditionally grown and consumed.

Both, chickpea and pigeon pea are a good source of protein as well as minerals and vitamins. Chickpea contains very less percentage of oil in their seeds. $\beta$ sitosterol, campesterol and stigmasterol are important sterols present in chickpea oil. The maximum amount of oil content reported was $6.9 \%$ (Zia-Ul-Haq et al., 2007). Most of the fatty acids in chickpea are unsaturated fatty acids, Calcium, Magnesium, Phosphorus and Potassium are present in chickpea and pigeon pea seeds. Chickpea is a good source of important vitamins such as riboflavin, niacin, thiamine, folate and vitamin A precursor $\beta$-carotene. Pigeonpea and chickpea seeds also contain anti-nutritional factors. Raffinose family oligosaccharides (RFOs), and $\alpha$-galactoside carbohydrates are the antinutritional factors present in chickpea and pigeon peaseeds. They cause flatulence in humans. However these negative effects can be reduced or eliminated by different cooking techniques. Chickpea and pigeon pea also possess high soluble and insoluble fibre, low glycaemic index, and are a good source for folate, phytoestrogens and saponins. They help in providing gluten- free diet. Pigeon pea was used traditionally in curing infant ailments and also known for possessing anti-diabetic and anti-mutagenic properties (Pal et al., 2011; Sanchez et al., 2016)

Preliminary studies on chickpea conducted at ICRISAT during 2011 and 2012 showed the existence of high variability in kernel iron (35-150 ppm) and zinc (25-50 ppm) contents both in cultivated as well as wild genotypes (Jukanti et al., 2014). The new genetic resources with high levels of iron and zinc are being used for improving the nutrient content in chickpea breeding lines using conventional breeding and shared with national and international partners. Further, the content of total carotenoids in wild species (9.1 $\mu \mathrm{g} \mathrm{g}^{-1}$ seed) was found to be higher than cultivated species $\left(4.5 \mu \mathrm{g} \mathrm{g}^{-1}\right)$ of chickpea (Abbo et al., 2005).

Groundnut kernels contain about $50 \%$ oil, $25 \%$ protein, and $14 \%$ carbohydrates. They provide 567 $\mathrm{kcal}$ of energy from $100 \mathrm{~g}$ of kernels (USDA nutrient database). Additionally, they also contain several health enhancing nutrients such as minerals, antioxidants, and vitamins. They contain antioxidants like $p$-coumaric acid, resveratrol, Vitamin E, and many important B-complex vitamins like thiamine, pantothenic acid, vitamin B-6, folates, and niacin. Groundnut is a dietary source of biologically active polyphenols, flavonoids, and isoflavones (Janila et al., 2015). Owing to their high nutritional content, groundnut and groundnut- based food products are promoted as nutritional food supplements and in readyto-use therapeutic foods (RUTFs) to combat energy, protein, and micronutrient malnutrition among acutely malnourished children and women. Groundnut in the form of flour, protein isolates and meal is desirable to prepare food supplements mixed with other grains. Groundnut protein products are being tested to add nutritional value to the diets of children in Senegal. Groundnut kernel skin contains phenolics with high antioxidant properties. As a food crop for home consumption, groundnut kernels are utilized in various forms: ground, boiled, roasted, paste etc. It is common to see different forms of snack items and confectionery made from groundnut. Roasted groundnut, shelled and unshelled is an important snack and pass-time food in India. It is normal to see vendors and children carrying roasted groundnut for sale on the streets. In general, it is a very important ingredient in the diet. 
Table 1: Nutrient values and weights are for edible portion of Pigeonpea, Chickpea and Peanut

\begin{tabular}{|c|c|c|c|c|}
\hline \multirow[t]{2}{*}{ Nutrient } & Unit & Pigeonpea $^{1}$ & Chickpea $^{2}$ & ${ }^{2}$ Peanut $^{3}$ \\
\hline & \multicolumn{4}{|c|}{1 Value per $100 \mathrm{~g}$} \\
\hline \multicolumn{5}{|l|}{ Proximates } \\
\hline Water & $\mathrm{g}$ & 10.59 & 7.68 & 6.5 \\
\hline Energy & kcal & 343 & 378 & 567 \\
\hline . $\quad$ Protein & $\mathrm{g}$ & 21.7 & 20.47 & 25.8 \\
\hline . $\quad$ Total lipid (fat) & $\mathrm{g}$ & 1.49 & 6.04 & 49.24 \\
\hline $\begin{array}{l}\text { Carbohydrate, } \\
\text { by difference }\end{array}$ & $\mathrm{g}$ & 62.78 & 62.95 & 16.13 \\
\hline $\begin{array}{l}\text { Fiber, total } \\
\text { dietary }\end{array}$ & $\mathrm{g}$ & 15 & 12.2 & 8.5 \\
\hline Sugars, total & $\mathrm{g}$ & - & 10.7 & 4.72 \\
\hline \multicolumn{5}{|l|}{ Minerals } \\
\hline - Calcium, $\mathrm{Ca}$ & $\mathrm{mg}$ & 130 & 57 & 92 \\
\hline Iron, $\mathrm{Fe}$ & $\mathrm{mg}$ & 5.23 & 4.31 & 4.58 \\
\hline · $\quad$ Magnesium, Mg & $\mathrm{mg}$ & 183 & 79 & 168 \\
\hline · $\quad$ Phosphorus, $\mathrm{P}$ & $\mathrm{mg}$ & 367 & 252 & 376 \\
\hline - $\quad$ Potassium, $\mathrm{K}$ & $\mathrm{mg}$ & 1392 & 718 & 705 \\
\hline - $\quad$ Sodium, $\mathrm{Na}$ & $\mathrm{mg}$ & 17 & 24 & 18 \\
\hline Zinc, Zn & $\mathrm{mg}$ & 2.76 & 2.76 & 3.27 \\
\hline \multicolumn{5}{|l|}{ Vitamins } \\
\hline $\begin{array}{l}\text { Vitamin } \mathrm{C} \text {, total } \\
\text { ascorbic acid }\end{array}$ & $\mathrm{mg}$ & 0 & 4 & 0 \\
\hline Thiamin & $\mathrm{mg}$ & 0.643 & 0.477 & 0.64 \\
\hline Riboflavin & $\mathrm{mg}$ & 0.187 & 0.212 & 0.135 \\
\hline Niacin & $\mathrm{mg}$ & 2.965 & 1.541 & 12.066 \\
\hline Vitamin B-6 & $\mathrm{mg}$ & 0.283 & 0.535 & 0.348 \\
\hline Folate, DFE & $\mu \mathrm{g}$ & 456 & 557 & 240 \\
\hline Vitamin B-12 & $\mu \mathrm{g}$ & 0 & 0 & 0 \\
\hline Vitamin A, RAE & $\mu \mathrm{g}$ & 1 & 3 & 0 \\
\hline . $\quad$ Vitamin A, IU & IU & 28 & 67 & 0 \\
\hline $\begin{array}{l}\text { Vitamin E } \\
\text { (alpha-tocopherol }\end{array}$ & mg & - & 0.82 & 8.33 \\
\hline $\begin{array}{l}\text { Vitamin D } \\
(\mathrm{D} 2+\mathrm{D} 3)\end{array}$ & $\mu \mathrm{g}$ & 0 & 0 & 0 \\
\hline Vitamin D & IU & 0 & 0 & 0 \\
\hline $\begin{array}{ll}\text { Vitamin K } \\
\text { (phylloquinone) }\end{array}$ & $\mu \mathrm{g}$ & - & 9 & 0 \\
\hline \multicolumn{5}{|l|}{ Lipids } \\
\hline $\begin{array}{l}\text { Fatty acids, } \\
\text { total saturated }\end{array}$ & g & 0.33 & 0.603 & 6.279 \\
\hline $\begin{array}{l}\text { Fatty acids, total } \\
\text { monounsaturated }\end{array}$ & $\mathrm{g}$ & 0.012 & 1.377 & 24.426 \\
\hline $\begin{array}{l}\text { Fatty acids, total } \\
\text { polyunsaturated }\end{array}$ & g & 0.814 & 2.731 & 15.558 \\
\hline $\begin{array}{l}\text { Fatty acids, total } \\
\text { trans }\end{array}$ & g & 0 & 0 & 0 \\
\hline
\end{tabular}

Source: USDA National Nutrient Database for Standard Reference 28 Software v.2.3.8.
${ }^{1}$ NDB Number 16101 (Pigeonpeas (red gram), mature seeds, raw). https://ndb.nal.usda.gov/ndb/foods/show/4839? manu=\&fgcd= ${ }^{2}$ NDB Number 16056 (Chickpeas (garbanzo beans, Bengal gram), mature seeds, raw). https://ndb.nal.usda.gov/ndb/foods/show/ 4795 ? fgcd $=$ Legumes + and + Legume + Products \& manu $=\& 1 f$ acet $=\&$ format $=\&$ count $=\& \max =35 \&$ offset $=\&$ sort $=\&$ qlookup $=$ Chickpea

${ }^{3}$ NDB Number 16087 (Peanuts, all types, raw). https://ndb.nal.usda.gov/ndb/foods/show/4825?fgcd= $\& \mathrm{manu}=\&$ lfacet $=\&$ format $=\&$ count $=\& \max =35 \&$ offset $=\&$ sort $=$ $\&$ qlookup $=$ peanut

Given the importance of chickpea, pigeon pea and groundnut for nutritional security and need to improve their availability and accessibility, there is urgent need to enhance the production and quality of the produce. In India, chickpea was cultivated in 9.6 $\mathrm{m}$ ha with a production of $8.8 \mathrm{~m}$ tons; pigeon pea in $4.6 \mathrm{~m}$ ha with a production of $3.0 \mathrm{~m} \mathrm{t}$, and groundnut in about $5.2 \mathrm{~m}$ ha with a production of $9.5 \mathrm{~m}$ t during 2013 (FaoSTAT 2013). There is scope to increase the production from the same area of cultivation through adoption of improved varieties, good management practices, and proper storage and postharvest handling. Demand for growth rate in India for groundnut is $2.41 \%$, for chickpea it is $1.7 \%$ and for pigeon pea $2.0 \%$ (IFPRI, IMPACT version 3.2, January 2016). The projected growth in demand of the three legumes implies need for intensification of their production through technological innovations to meet the domestic demand.

\section{Biofortified Grain Legumes}

Biofortification is delivery of micronutrients via micronutrient-dense crops. It offers a cost-effective and sustainable approach for addressing the issue of micronutrient deficiencies in humans (Grusakand and Della Penna, 1999). If there is sufficient genetic variation for the density of micronutrients in edible parts of the crop, biofortification can be achieved through plant breeding (Mayer et al., 2008), wherein, new crop varieties with elevated nutrient content can be developed for cultivation and production of nutrientdense foods. Biofortification can be achieved through conventional means or through transgenic technologies. However, several countries world over have imposed restriction on deploying transgenic technology for food crops. Biofortification to some extent can be achieved through agronomic management practices. 
Biofortification of staple cereals and some legumes has been successful. Maria Andrade, Robert Mwanga, Jan Low and Howarth Bouis were announced as the 2016 Laureates of the World Food Prize for their pioneering work in the implementation of biofortification as a global plant breeding strategy. As a result, crops such as iron and zinc fortified beans, rice, wheat and pearl millet, along with Vitamin Aenriched cassava, maize and OFSP (orange-fleshed sweet potatoes) are being tested or released in over 40 countries including India (http://www.harvestplus. org). HarvestPlus is developing and promoting biofortified staple crops to improve human health and nutrition, and providing global leadership on biofortification evidence and technology. Golden rice with $\beta$-carotene (Paine et al., 2005), orange-flesh sweet potato varieties with high levels of $\beta$-carotene of over $200 \mu \mathrm{g} / \mathrm{g}$, and beans with improved agronomic traits and grain type with $50-70 \%$ more iron have been developed successfully and commercialized. Iron-biofortified pearl millet variety developed by ICRISAT (ICTP-8203Fe), named Dhanashakti was commercialized in Maharashtra by HarvestPlus by partnering with Nirmal seeds. Children aged between 12-16 who were found to be iron deficient recovered dramatically after they were fed for four months with "bhakhri" (flat unleavened bread) in their mid-day meal (www.icrisat.org). A clinical trial (registered at clinicaltrials.gov as NCT02152150)conducted in Maharashtra showed that among children who were iron deficient at baseline, and had received ironfortified pearl millet were 1.64 times more likely to become iron replete by 6 months than were those who received Control-pearl millet (Finkelstein et al., 2015). A study on primary school children showed that feeding $\beta$-carotene-rich sweet potato improved their vitamin A status (Van Jaarsveld et al., 2005). Targeting malnutrition through biofortified crops is a highly cost effective and a sustainable option with least side effects (Nestel et al., 2006). Consumption of iron-biofortified beans for a period of 4.5 months improved iron status in iron depleted women in Rwanda (Haas et al., 2015).

In groundnut, significant variability in oil, protein, iron and zinc content was observed (Table 2a, 2b). Biofortified groundnut lines with high $\mathrm{Fe}$ and $\mathrm{Zn}$ in kernels were identified (Janila et al., 2014) and recently 'high oleic' lines were developed (Janila $e t$ al., 2015). The kernels from high $\mathrm{Fe}$ and $\mathrm{Zn}$ lines will
Table 2a: Variation in kernel iron and zinc concentration of selected groundnut genotypes evaluated at ICRISATPatancheru

\begin{tabular}{lcc}
\hline Genotypes & Fe $(\mathrm{mg} / \mathrm{Kg})$ & $\mathrm{Zn}(\mathrm{mg} / \mathrm{Kg})$ \\
\hline CS 39 & 58.2 & 73.9 \\
ICGV 06099 & 57.3 & 81.0 \\
GPBD 4 & 55.5 & 70.5 \\
U4-47-7 & 52.1 & 69.0 \\
Leaf Mutant & 51.1 & 67.2 \\
ICGV 91114 & 50.6 & 66.2 \\
ICGV 87157 & 49.4 & 68.4 \\
ICGV 93437 & 48.6 & 61.5 \\
ICGV 86590 & 46.3 & 64.9 \\
Goldin-1 & 45.0 & 61.2 \\
ICGV 07356 & 43.5 & 55.3 \\
ICGV 89280 & 42.8 & 60.0 \\
\hline
\end{tabular}

Table 2b: Variation in oil and protein concentration in selected groundnut genotypes evaluated at ICRISATPatancheru

\begin{tabular}{lcc}
\hline Groundnut genotype & Oil $(\mathrm{mg} / \mathrm{Kg})$ & Protein $(\mathrm{mg} / \mathrm{Kg})$ \\
\hline ICGV 06420 & 570 & 221 \\
ICGV 05155 & 562 & 220 \\
ICGV 06040 & 545 & 250 \\
ICGV 07247 & 525 & 256 \\
Erget & 510 & 228 \\
ICGV 91114 & 501 & 230 \\
ICGV 89280 & 496 & 208 \\
GNL mutant & 490 & 231 \\
ICGV 86015 & 487 & 232 \\
K 4-11 & 474 & 222 \\
Large Leaf & 461 & 236 \\
ICGV SM 90704 & 457 & 253 \\
\hline
\end{tabular}

Note: Data presented in 2a and $2 \mathrm{~b}$ is taken from Janila et al., 2014. ICGV=ICRISAT Groundnut Variety, K=Kadiri, ICGV SM=ICRISAT Groundnut Variety Selection Malawi

be useful in preparing ready-to-use-therapeutic food (RUTF) products to treat acute malnutrition. Dietary oleic acid offers several health benefits such as decreasing the risk of cardio-vascular diseases by reducing the levels of serum low-density lipoproteins and maintaining levels of high-density lipoproteins (HDL); suppression of tumorigenesis, and amelioration of inflammatory diseases (O'Byrne et al., 1997). 
'High oil' groundnut lines were recently identified for release in India. High oil content of these lines further increases energy per unit mass, making them suitable for high energy food supplements. 'High oleic' groundnut benefits food processing industry through enhanced shelf-life owing to lower oxidation of oleic acid compared to linoleic acid. Recently, ICRISAT has developed 'high oleic' groundnut varieties following marker assisted backcrossing (MABC) and marker assisted selection (MAS) approaches. Varieties such as ICGV 15033 (85\% Oleic acid), ICGV 15035 (82\%), ICGV 15002 (79\%) and ICGV 15036 (75\%) have high oleic acid content of $75 \%$ and above, while the normal cultivated varieties have $36-52 \%$. Two mutant fatty acid desaturase ( $a h F A D)$ alleles in the A-genome (linkage groupa09) and in the B-genome (linkage group b09) confer 'high oleic' trait in groundnut. Allele specific and CAPS (cleavedamplified polymorphic segment) markers were used to select $a h F A D$ mutant alleles in segregating populations (Janila et al., 2015).

At ICRISAT, efforts are being made to develop groundnut varieties enriched with pro-Vitamin A. The "International Peanut Genome Initiative (IPGI)" has decoded the genomes of two diploid progenitors representingA-genome (Arachisduranensis, accession V14167) and B-genome (Arachisipaensis, accession K30076) (http://peanutbase.org/genomes). Draftgenome sequence for A. duranensis (accession

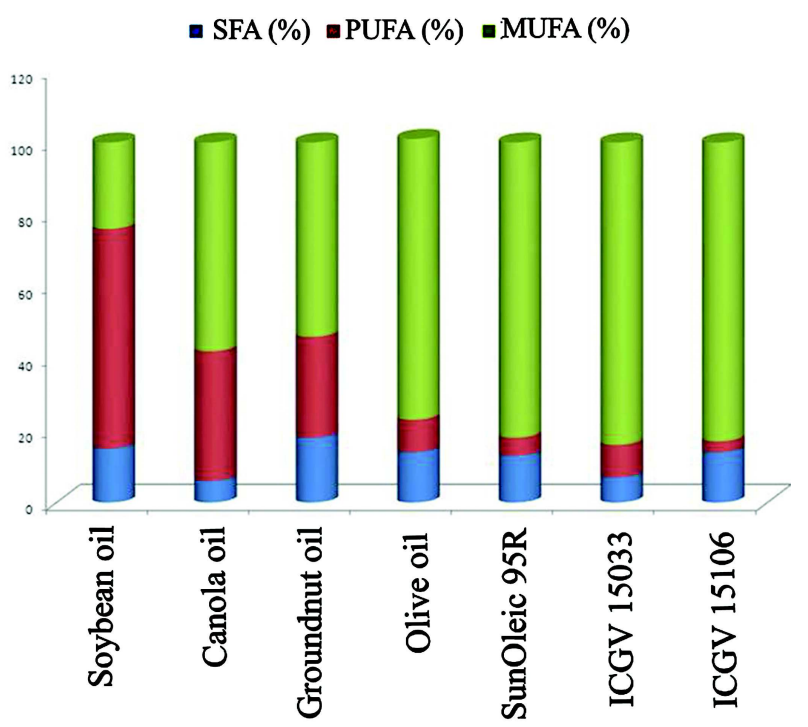

Fig. 1: Fatty acid profile of some commonly used vegetable oils and 'high oleic' groundnut lines. SFA=saturated fatty acids, PUFA=poly unsaturated fatty acids, MUFA=Mono unsaturated fatty acids
PI475845) was completed by "Diploid Progenitor Peanut A-genome Sequencing Consortium (DPPAGSC)". The genome sequences will accelerate gene discovery, development of genomic resources, and their deploymentin breeding programs for accelerated varietal development which includes Biofortification with micronutrietnts.

Significant variation exists in pigeon pea germplasm for iron and zinc content which is untapped. Saxena et al. (2010) reported iron content of $4.6 \mathrm{mg}$ $100 \mathrm{~g}^{-1}$ in green seeds of pigeon pea, which is higher than mature seeds containing $3.9 \mathrm{mg} 100 \mathrm{~g}^{-1}$. The variability in iron among pigeon pea germplasm is from 2.5 to $5.3 \mathrm{mg} / 100 \mathrm{~g}$. Zinc content of $2.5 \mathrm{mg} 100$ $\mathrm{g}^{-1}$ was slightly higher in green seeds as compared to mature seeds containing $2.3 \mathrm{mg} 100 \mathrm{~g}^{-1}$. Pigeon pea germplasm shows significant variation for kernel zinc content, -2.3 and $8.2 \mathrm{mg} / 100 \mathrm{~g}$. With significant variation observed for kernel iron and zinc content in pigeon pea seeds it is possible to develop biofortified pigeon pea varieties with elevated levels of iron and zinc. Genetic studies on identification of quantitative trait loci governing carotenoid concentration in chickpea (Abbo et al., 2005) are expected to contribute to breeding new chickpea varieties with enhanced carotenoid concentration.

Reducing the concentration of RFO's (Raffinose family of oligosaccharides ), theanti-nutritional factors that cause flatulence, improves nutritional value of chickpeas and its acceptance among consumers. Studies have shown a wide genotypic variation in total

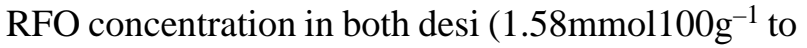

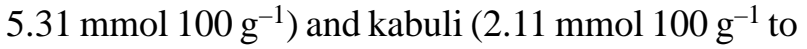
$5.83 \mathrm{mmol} 100 \mathrm{~g}^{-1}$ ) chickpea (Gangota et al.,), indicating possibility of developing varieties with low RFO contents 2013.

\section{Processed Grain Legumes as Food Supplements to Treat Acute Malnutrition}

Supplementation of cereals with legumes rich in protein is considered as the best solution to address malnutrition in developing countries. Nutritional quality of pigeonpea is well reviewed, however commercial processing of products derived from pigeonpea are not popular. Annual production of groundnuts in India is about $9 \mathrm{mt}$ but very little is processed. Khedut feeds and foods private limited based in Gujarat state is one of the processing unit in the country handling large 
quantities of groundnut using state-of-art technologies (Khedut Feeds and Foods, 2016). The processing plant has a capacity to handle 125 tons per day $(45,000$ MT per year) to provide quality groundnuts to national and export markets (Khedut Feeds and Foods, 2016). In recent years, scientific research has focused on optimizing food-products of groundnut, done by characterization and quantification of groundnut proteins, edible fibre, phenolic compounds and their potential effects. This hasprompted investigations on the effects of nutritional composition of groundnuts on human health and nutritional quality in processed food products (Zhao et al., 2012). Chickpea is the most appreciated and more widely analyzed legume for its health properties in recent years. International Agency for Research on Cancer (IARC) considers acrylamide as carcinogenic to humans. Extensive research to lower acrylamide content in cereals and potato which are rich in carbohydrates has been documented. Acrylamide is an anti-nutritional substance present in breads, snacks and chips formed by Maillard reaction between carbohydrates and amino acids at high temperatures. Addition of chickpea to flour is anew way to reduce the content of acrylamide in such products (Rachwa-Rosiak et al., 2015). Dough made with addition of $10 \%$ chickpea has $2.5 \%$ lower carbohydrate content than dough prepared with wheat flour, as chickpea flour has lower carbohydrate content than wheat flour. Lower availability and amount of carbohydrates present in the raw materials for confectionery may lead to a lessening of the Maillard reaction, and thus prevent the intermediate reactions leading to the formation of acrylamide.

Groundnut protein isolates have been developed to alleviate protein-caloriemalnutrition problem. Groundnut-fortified foods in combination with other cereals, legumes, root crops have been reviewed earlier by Singh and Singh (1991). Abdel et al. (1980) found that flours containing $15 \%$ groundnut in place of wheat flour did not affect the quality of cake. Groundnut protein isolates after industrial processing of oil is suitable for baking products. Confectionaries using roasted groundnuts are common in markets.

Ready-to-use-therapeutic-food (RUTF) products are widely used to treat acute malnutrition, particularly among the vulnerable groups of children and women. Food products based on groundnut meet the key criteria of availability, affordability, acceptability, nutritional quality and business interestthe necessary criteria for foods to reduce undernutrition (Henry et al., 2013). In a study conducted in Ghana, groundnut was identified as important crop having potential for contributing to nutritional security. Donors including USAID consider groundnut as one of the important crops for reducing malnutrition. Projects like 'SPRING nutrition' in Ghana and 'Groundnut Scaling' in Mali, Ghana and Nigeria promote home consumption of groundnut for enhanced nutrition. RUTF products based on groundnut are low cost and of proven solutions in treating malnutrition among children and women. 'PlumpyNut', a RUTF is used by UNESCO to treat acute malnutrition in children in Niger. Project peanut butter operating in Malawi, Sierra Leone and Ghana uses groundnut based RUTFs as cost-effective solution to eradicate malnutrition ( $w w w$. projectpeanutbutter.org).

Presently UNICEF's RUTF programme feeds 2.6 million children in Africa (UNICEF, 2014). UNICEF initiated procurement of 34,000 MT of groundnut based RUTF paste during the year 2014. This RUTF paste is a dense micronutrient filled energy mixture of groundnuts, sugar, oil and milk powder suitable for children aged 6-24 months.

Nutrient mixture of sorghum-peanut blend (SPB) with honey and ghee has been used to treat acute malnutrition in Uganda in infant and young children. Vitamin A, iron, zinc, calcium, magnesium, phosphorus, potassium, manganese and sodium in the blend was found to be adequate for recovery from acute malnutrition. SPB also possessed energy content of about $430 \mathrm{kcal} / 100 \mathrm{~g}$ (Amegovu et al., 2013).

Groundnut based drinkable infant food was developed to prevent and manage malnutrition. A processing protocol for three plant food formulations yielding nutrient-dense, easily digestible and safe therapeutic food for malnourished children was developed in Uganda. The blend was prepared using golden amaranth grain along with groundnuts, sesame, beans and cowpeas (Nabuumaet al., 2013).

A network of nine independent producers manufacturing nutritional products to treat and prevent malnutrition in endemic regions of developing world has been formed under the banner PlumpyField 
(www.Plumpyfield.com). Plumpy'Nut as RUTF to address severe acute malnutrition, and Plumpy'Sup as RUSF (Ready-to-use-supplementary Food) to address moderate acute malnutrition have been prepared. In addition, Plumpy 'Doz and Plumpy' Mum for infant, pregnant and lactating women are popularised through PlumpyField network. There was limited success when Plumpy'Nut was introduced in the states of Bihar, Maharashtra and Jharkhand by UNICEF. However, there are opportunities to develop indigenous products like 'Chiki', groundnut cake blended with sugarcane jaggery. There are other nutrient mixtures like Davangere mix, Shakti nutrimix, Lapsietc which contain groundnut in significant proportions. Beesabathuni and Natchu (2010) have indicated the urgency in tackling severe acute malnutrition among Indian children as a priority through community management in partnership with civil society as RUTF ingredients are widely available in India.

Chickpea is the key ingredient in hummus, a popular processed chickpea paste. Chickpea has been used as a RUTF in chronically malnourished adults with confirmed or suspected AIDS in developing countries like Malawi (Bahwere et al., 2011). World Food Programme has successfully implemented 'Wawa Mum', a special chickpea-based RUTF product for infants and growing children made from locally grown chickpeas. Wawa Mum wraps a day's worth of nutrients and vitamins in a single $50 \mathrm{~g}$ serving that can be eaten directly from the pack. RUTFs are becoming popular to treat malnutrition because of convenience as there is no cooking and processing needed at the consumption end. The obvious benefits were observed during emergency times of flooding and in addressing refugee children. There is a growing demand for 'Wawa mum' in Pakistan. It is suitable for integration into government programs in India as well, especially in locations where chickpea is grown. Realization of potential use of chickpea products to improve nutrition of school children in rural areas is possible as there is a scope of introducing chickpea and groundnut products into government run mid-day meal scheme.

Guts Agro industry has launched different types of chickpea based products for Ethiopian markets. Products like chickpea shiro powder branded as 'YanetShiro', a RUSF and a dry roasted chickpea product, 'Kolo'are used for not only domestic markets but also in addressing acute malnutrition in Ethiopian children (Guts Agro, 2016).

A UNDP (2016) case study of inclusive business model where poor on both sides of demand and supply have been effectively implemented in Ethiopia through a public-private-partnership model. Over 10,000 smallholder farmers in Ethiopia's Shewa and Gondar provinces and local manufacturers are benefited through an alliance with World Food Programme of the United Nations, USAID and Government of Ethiopia to produce RUSF from chickpeas. PepsiCo, world's largest producer of chickpea based products like 'Sabra Hummus' dips, partnered with this inclusive market growth model in Ethiopiato alleviate severe malnutrition in this region.

There is potential for utilizing Chickpea Liquid Meal (CLM), a product based on chickpea having high nutritional quality and functional properties - a concept developed by Kusnandar et al. (2002).A chickpea- based infant formula that meets WHO/FAO requirements has been prepared by germinating chickpea for 72 hours, followed by boiling, drying and de-hulling (Malunga et al., 2014). Chickpea protein can be used for the preparation of micro-encapsulates that carry nutrients such as vitamins in foods. This was demonstrated by Ariyarathna and Karunaratne (2015) in their study for encapsulation of vitamin B9 (folate). This process of protein encapsulation has been found to be beneficial for improving the stability of folate in processed foods.

Green pigeon pea seeds are commercially available as canned foods in the markets in the developed countries. In India, with large area under pigeon pea, it is possible to popularize the cultivation and use of green pigeon pea for improving the diet of vegetarians. Green pigeon pea cultivation can be practiced on a commercial farm or in kitchen gardens. Similarly a number of products as snacks like biscuits, cakes, noodles etc. can be made from pigeonpea. Popularisation of these technologies makes valueadded products of pigeon pea available in markets.

The potential of using processing technologies of legumes is still in infancy. There are immense opportunities for researchers and developers of new products to harness the nutritional advantage of legumes for addressing the problem of malnutrition. 
However, there is also need for food safety and standardization protocols, and regulations in developing countries like India for such products.

\section{Antinutrients, Contaminants and Food Safety}

Antinutrients are natural compounds that interfere with absorption of nutrients. They are present in varied levels in all the grains. However, domestication has resulted in reduced concentration of antinutrients in cultivated crops. The antinutrients may be naturally occurring and offering protection to invasion of pathogens or may be produced as secondary metabolites in response to stress as plant defence mechanism and contribute to enhanced crop productivity. The concentration of antinutrients, rather than their mere presence in grains is of concern. Food processing methods like fermentation, soaking, baking and boiling are known to reduce the load of some of the antinutrients (El-adawy, 2002). Complete elimination of antinutrients is neither required nor desirable given their key role in plant metabolism and defence mechanisms. However, there is scope to reduce the concentration of antinutritional factors using selection of genotypes with low content and/or through food processing techniques.

Phytic acid is an important antinutritional factor in cereals and legumes. It gets rapidly accumulated in all seeds during the process of ripening. It contains phosphorus. Phytates are essential for seed germination. Phytates strongly bind to metal ions, like zinc, copper, calcium, magnesium and iron in gastrointestinal tract and thus inhibit the absorption of these metals. They particularly have strong affinity for zinc. Zinc deficiency in populations whose major source of protein is legumes is attributed to phytic acid in the legumes. Phytates bind to protein reducing protein solubility and enzyme activity. Phytin (myoinositol hexaphosphate) a naturally occurring form of phytic acid is a mixed magnesium and potassium salt of phytic acid. It forms insoluble precipitates with calcium, magnesium and iron and consequently reduces their absorption. It is possible to enhance the nutritional value of chickpea and pigeonpea by reducing the concentration of phytic acid. In iron and zinc biofortified varieties of groundnut, selecting genotypes that combine higher levels of iron and zinc with lower concentration of phytic acid is desirable. Some studies however, suggest health benefits of phytates in foods to enhance the immune system, and possible anti-cancer and serum cholesterol-lowering effects.

Trypsin inhibitors and polyphenols like tannins are other antinutrients in chickpea and pigeon pea. They inhibit digestive enzymes and thus reduce digestibility and absorption of dietary protein and carbohydrates.

Flatulence caused by consumption of chickpea is associated with the presence of raffinose-series of oligosaccharides, -important antinutritional factors. They are metabolized in lower intestine by bacterial action producing methane, carbon dioxide and hydrogen causing flatulence and diarrhoea. Pigeonpea seed coat is rich in polyphenols, which are antinutritional factors. However, some white seeded pigeonpea cultivars containing relatively less amounts of polyphenols are also available. These cultivars are preferred in many countries where de-hulling facilities are not available and whole seeds are consumed. In comparison to the white seeded cultivars, the red seeded types contain three times greater quantity of polyphenols. Similarly, the tripsininhibition activity was also greater in the coloured seeds of pigeonpea. In India almost entire pigeonpea production is converted into dal, the process in which seed coat is removed and, therefore, the tannins present in the coloured seed coat pose no problem for consumption (Saxena, 2010).

Aflatoxin contamination in groundnut, caused by pre- or post-harvest infection by Aspergillus flavus fungus is a major food safety and trade concern. Aflatoxins are secondary metabolites produced by the fungus species, Aspergillus and are potent carcinogens. Several countries across the globe have imposed stringent regulations on level of aflatoxin in the groundnut imports. Since the infection can happen pre-harvest and post-harvest, a combination of methods that can prevent infection at both these stages is desirable. Host-resistance combined with management practices can effectively manage preharvest infection. Breeding lines with moderate tolerance to Aspergillus infection in the field have been identified at ICRISAT and elsewhere (Nigam et al., 2009). However, stable level of tolerance is a challenge and desirable levels of resistance are not available in the germplasm. Trangenics with tolerance to Aspergillus infection have potential to contain preharvest infection. Toleranceto infection results in reduced aflatoxin contamination. Peanut lipoxygenase 
(PNLOX13S) gene which blocks the synthesis of aflatoxin in groundnut was used and some putative transgenics with the gene were identified at ICRISAT. Protocols for screening and evaluation of transgenics for Aspergillus flavus infection and aflatoxin production are being optimized. Post-harvest handling that includes drying and storage methods are important to manage post-harvest infection. Monitoring the contamination levels along the processing chain is desirable for export markets. APEDA (Agricultural Processing and Export Development Authority) is providing services through peanutnet (www. peanutnet.org) for monitoring contamination through accredited laboratories and traceability of export consignments. However, lack of awareness among the consumers and absence of regulatory framework for monitoring and labelling contamination in India result in consumers being exposed to aflatoxin contamination through various food items including corn and groundnut products.

Technologies to mitigate aflatoxin contamination in groundnutinclude: breeding varieties resistant to Aspergillus flavus seed infection and aflatoxin contamination; biocontrol agents for reducing preharvest aflatoxin contamination (PAC), and good agricultural practices (GAPs) comprising of processing, handling and storage practices. Peanut and Mycotoxin Innovation Lab (PMIL) is supporting a project with a goal to develop molecular markers associated with resistance to pre-harvest aflatoxin contamination and to utilize this information in breeding programs to accelerate development of new varieties. Groundnut genome sequence information, of the cultivated tetraploid groundnut species $(2 n=4 x=40)$ as well as diploid progenitors of the tetraploid species enabled genotyping using genome wide SNP markers. A multi-parent advanced generation inter-cross (MAGIC) population involving eight parents is derived to develop genomic tools for resistance to Aspergillus infection and aflatoxin contamination. Research to understand host-pathogen interactions and

\section{References}

Abbo S, Molina C, Jungmann R, Grusak M A, Berkovitch Z, Reifen R, Kahl G, Winter P and Reifen R (2005) QTL governing carotenoid concentration and weight in seeds of chickpea (Cicer arietinum L.) Theor Appl Genet 111 185195 identification of candidate genes is in progress to better target the problem of aflatoxin contamination in groundnut.

Groundnut butter as a source for the outbreak of Salmonella was reported in 2009, through a Georgia groundnut manufacturer (Chang et al., 2013). Hence the need to standardize good manufacturing practices (GMPs) to address and prevent contamination of processed food products is non-negotiable.

\section{Summary}

Nutritional security is a priority in India. The pathways between agriculture production and nutrition security suggest that crop diversification contributes to balanced diets. Intensification of production of nutrientdense grain legumes increases accessibility at affordable cost to meet nutritional needs. Policy options such as inclusion of millets and grain legumes under public distribution system (PDS) are needed immediately to improve accessibility to diverse and nutrient- dense foods to the large majority of people in the country, who depend on PDS for food security. Technological innovations that include improved grain legume varieties adapted to target ecologies and meet the production challenges, intensification of cultivation through adoption of better management practices, and tap the genetic variation of various nutritional quality traits through development of biofortified varieties such as high iron and zinc groundnut lines will help to fight micronutrient deficiencies in the country. Genomic tools and robust phenotyping tools to assess the quality will enable improvement in nutritional quality in new varieties. Scientific innovations and/or awareness in handling are needed to plug postharvest and storage losses of grain legumes. Processing technologies to develop products for varied nutritional needs including treatment of acute malnutrition and reducing antinutrients need to be developed. Innovations and awareness to address food safety concerns are also wanted.

Abdel M M, El-Samahy K S, Scieha H and Morad M M (1980) Cake mix supplementation with soybean, sweet potato or peanut flours Chemical, mocrobiological and rheological studies Bakers' Digest 54 28-30

Amegovu A K, Ogwok P, Ochola S, Yiga P, Musalima J H and Mutenyo E (2013) Formulation of sorghum-peanut blend 
using linear programming for treatment of moderate acute malnutrition in Uganda J Food Chem Nutri 1 67-77

Ariyarathna I and Karunaratne D N (2015) Use of chickpea protein for encapsulation of folate to enhance nutritional potency and stability Food and Bioproducts Processing 95 76-82

Bahwere P, Deconinck H, Banda T and Collins S (2011) Effective therapeutic feeding with chickpea sesame based ready-touse therapeutic food (CS-RUTF) in wasted adults with confirmed or suspected AIDS World JAIDS 1 169-181

Barker M G, Chorghade S, Crozier S, Leary S and Fall C (2006) Gender differences in body mass index in rural India are determined by socio-economic factors and lifestyle $\mathrm{J} \mathrm{Nutr}$ 136 3062-3068

Beesabathuni K N and Natchu U C M (2010) Production and distribution of a therapeutic nutritional product for severe acute malnutrition in India: Opportunities and challenges Indian Pediatrics $\mathbf{4 7}$ 702-706

Bhagowalia P, Headey D D and Kadiyala S (2012) Agriculture, income, and nutrition linkages in India: insights from a nationally representative survey. IFPRI Discussion Paper 01195. Washington, DC Int Food Policy Res Inst

Bhalotra S (2010) Fatal fluctuations? Cyclicality in infant mortality in India $J$ Dev Econ 93 7-19

Chang A S, Sreedharan A and Schneider K R (2013) Peanut and peanut products: A food safety perspective Food Control 32 296-303

Deaton A and Dreze J (2009) Food and nutrition in India: Facts and interpretations Econ and Political Weekly 44 42-65

El-Adawy T A (2002) Nutritional composition and antinutritional factors of chickpeas (Cicer arietinum L.) undergoing different cooking methods and germination Plant Food for Human Nutri 57 83-97

FAO (2011) Global food losses and food waste - Extent, causes and prevention. Rome

FAO STAT (2013) www.fao.org accessed on 16-4-2016

Finkelstein J L, Mehta S, Udipi S A, Ghugre P S, Luna S V, Wenger M J, Murray-Kolb L E, Przybyszewski E M and Haas J D (2015) A Randomized Trial of Iron-Biofortified Pearl Millet in School Children in India J Nutr 2015 Jul; 145 1576-81 doi: 10.3945/jn.114.208009. Epub 2015 May 6

Gangola M P, Khedikar Y P, Gaur P M, Båga M and Chibbar R N (2013) Genotype and growing environment interaction shows a positive correlation between substrates of raffinose family oligosaccharides (RFO) biosynthesis and their accumulation in chickpea (Cicer arietinum L.) seeds J Agric Food Chem 61 4943-4952
Grusak M A and Dellapenna D (1999) Improving the nutrient composition of plants to enhance human nutrition and health Annu Rev Plant Physiol and Plant Mole Biol 50 133161

Guts Agro (2016) YanetShiro: chickpea based Ready to use supplementary food. www.gutsagroindustry.com/ index.php/our-products.html accessed on 18-4-2016

Haas J, Luna S, Lung' aho M, Ngabo F, Wenger M, Murray-Kolb L, Beebe S, Gahutu J B and Egli I (2015) Iron bio fortified beans improve iron status in Rwandan University women: Results of a feeding trial (646.1) FASEB J 28646.1

Henry Anim-Somuah, Spencer Henson, John Humphrey and Ewan Robinson (2013) Evidence Report No. 28. Reducing Hunger and Undernutrition. Policy Guidelines: Enhancing Markets for Nutrient-Dense Foods in Ghana. Institute of Development Studies, England http://opendocs.ids.ac.uk/ opendocs/bitstream/handle/123456789/2958/ER28\%20 Final\%20Online.pdf? sequence $=3$

Janila P, Nigam S N, Abhishek R, Anil Kumar V, Manohar S S and Venuprasad R (2014) Iron and zinc concentrations in peanut (Arachis hypogaea L.) seeds and their relationship with other nutritional and yield parameters J Agric Sci doi: 10.1017/S0021859614000525

Janila P, Pandey M K, Shasidhara Y, Murali T V, Sriswathi M, Khera P, Manohar S S, Nagesh P, Vishwakarma M K, Mishr G P, Radhakrishnan T, Manivannan N, Dobariya K L, Vasanthi R P and Varshney R K (2015) Molecular breeding for introgression of fatty acid desaturase mutant alleles (ahFAD2A and ahFAD2B) enhances oil quality in high and low oil containing peanut genotypes Plant Sci 242 203-213 http://dx.doi.org/10.1016/j.plantsci.2015. 08.013

Jukanti A K, Gaur P M, Gowda C L L and Chibbar R N (2014) Nutritional quality and health benefits of chickpea (Cicer arietinum L.): A review Br J Nutr 108 S11-26 doi: 10.1017/ S0007114512000797

Kandiyala S, Harris J, Headey D, Yosef S and Gillespie S (2014) Agriculture and nutrition in India: mapping evidence to pathways Ann NY Acad Sci 1331 43-56

Khedut Feeds and Foods (2016) Peanut processing unit. www.kanbifoods.com accessed on 18-4-2016

Kusnandar F, Tumalllii F and Hosken R W (2002) UHT processed chickpea liquid meal: A novel concept of a convenient liquid food Indonesian Association of Food Technol 12 8696

Lal R R and Verma P (2007) Post harvest management of pulses. Indian Institute of Pulses Research, Kanpur

Malunga L N, Dadon S B E, Zinal E, Berkovich Z, Abbo S and 
Reifen R (2014) The potential use of chickpeas in development of infant follow-on formula Nutr J 13 1-6

Mayer J E, Pfeiffer W H and Beyer P (2008) Bio fortified crops to alleviate micronutrient malnutrition. Current Opinion in Plant Biol 11 166-170

Nabuuma D, Nakimbugwe D, Byaruhanga Y B, Saalia F K, Phillips R D and Chen J (2013) Development of the process for a drinkable plant-based infant food J Nutr Food Sci 3 1-7

Nagpal M and Kumar A (2012) Grain losses in India and government policies Quality Assurance and Safety of Crops \& Foods 4 143-150 DOI: 10.1111/j.1757-837X.2012. 00150.x

Narayanan S and Gerber N (2016) Social safety nets for food and nutritional security in India.Working Paper 146. Zentrum fur Ent wick lungs for schung, Centre of Development Research, Bonn, Germany

Nestel P, Bouis H E, Meenakshi J V and Pfeiffer W (2006) Biofortification of Staple Food Crops. In: Food Fortification in Developing Countries given at the 2005 Experimental Biology meeting, Am Society for Nutrition, April 5, 2005, in San Diego, CA

Nigam S N, Waliyar F, Aruna R, Reddy S V, Lava Kumar P, Craufurd P Q, Diallo A T, Ntare B R and Upadhyaya H D (2009) Breeding Peanut for Resistance to Aflatoxin Contamination at ICRISAT Peanut Sci 36 42-49

O’Byrne D J, Knauft D A and Shireman R B (1997) Low fat, mono-saturated rich diets containing high oleic peanuts improve the serum lipoprotein profiles Lipids 32 687-695

Paine J A, Shipton C A, Chaggar S, Howells R M, Kennedy M J, Vernon G, Wright S Y, Hinchliffe E, and Adams J L (2005) A new version of Golden Rice with increased pro-vitamin A content. Nat Biotechnol 23 482-487

Pal D, Mishra P, Sachan N and Ghosh A K (2011) Biological activities and medicinal properties of Cajanus cajan (L.) Millsp. Journal of Advanced Pharmaceutical Technology and Research 4 207-214

Panda M and Ganesh-Kumar A (2009) Trade liberalization, poverty, and food security in India.IFPRI Discussion Paper 00930 Washington DC Int Food Policy Res Inst

Pangaribowo E H, Gerber N and Torero M (2013) Food and nutrition security indicators: A review. Working paper 108, Centre for Development Research, University of Bonn

Rachwa-Rosiak D, Nebesny R E and Budryn G (2015) Chickpeascomposition, nutritional value, health benefits, application to bread and snacks: A review Critical Reviews in Food Sci Nutr 55 1137-1145
Sanchez G C, Tanquilut N C, Tanquilut M R C, Soriano J H R, Mula M G and Mula R P (2016) Anticlastogenic potential of pigeonpea (Cajanus cajan (L.) in white mice (Mus musculus L.) Green Farming 7 357-360

Saxena K B, Vijaykumar R and Sultana R (2010) Quality nutrition through Pigeonpea A review Health 11 1335-1344

Singh B and Singh U (1991) Peanut as a source of protein for human foods Plant Foods for Human Nutr 41 165-177

UNDP (2016) PepsiCo: partnering with international development organizations to scale up chickpea production and fight malnutrition in Ethiopia. http://www.undp.org/ content/dam/undp/library/corporate/Partnerships/ Private\%20Sector/AFIMcases/UNDP\%20GIM\% 20Case $\% 20$ Study\%20PepsiCo\%20Final.pdf accessed on $18-4-2016$

UNICEF (2014) Ready-to-Use Therapeutic Food: current outlook www.unicef.org/supply/files/RUTF_Supply_ Update_May_2014.pdf accessed on 18-4-2016

United States Department of Agriculture (2014) Agricultural Research Service, National Nutrient Database for Standard Reference Release 27. http://ndb.nal.usda.gov/ndb/foods/ (accessed on 22 Feb 2015)

US Embassy (2015) American support local industry to fight malnutrition in Sudan. Press release. http://sudan. usembassy.gov/pr-030215.html accessed on 18-4-2016

Van Jaarsveld P J, Faber M, Tanumihardjo S A, Nestel P, Lombard C J and Benadé A J S (2005) â-Carotene-rich orange-fleshed sweet potato improves the vitamin A status of primary school children assessed by the modified-relative-doseresponse test Am J Clin Nutr 81 1080-1087

Varadharajan K S, Thomas T and Kurpad A V (2013) Poverty and the state of nutrition in India Asia Pacific J Clinical Nutr 22 326-339

Wiggins S and Keats S (2013) Smallholder agriculture's contribution to better nutrition. Overseas Development Institute Report commissioned by Hunger Alliance

Zhao X, Chen J and Du F (2012) Potential use of peanut byproducts in food processing: A review J Food Sci Technol $49521-529$

Zia-Ul-Haq M, Ahmad M, Iqbal S, Ahmad S and Ali H (2007) Characterization and Compositional Studies of Oil from Seeds of Desi Chickpea (Cicer arietinum L.) Cultivars Grown in Pakistan J Am Oil Chem Soc 84 1143-1148. 